\title{
A Case Study on Multimodality Teaching in a College English Listening and Speaking Course
}

\author{
Ji Song* \\ College English Teaching Department, Dezhou University, Dezhou, Shandong, China
}

*Corresponding Author: Ji Song, College English Teaching Department, Dezhou University, Dezhou, Shandong, China

\begin{abstract}
The research investigates multimodality teaching in a college English course of viewing, listening and speaking for undergraduates majored in accounting, which makes the most of its advantages from language and non-language aspects. It is a useful exploration for teaching reform of college English listening and speaking lesson. Finally, the paper gives suggestions for multimodal English listening and speaking instruction from the application of multimodality and media system.
\end{abstract}

Keywords: Multimodality, English Listening And Speaking Course, Language, Non-Language, College English

\section{INTRODUCTION}

College English viewing, listening and speaking is a new compulsory course after English teaching reform was launched among universities in China early in the 21st century. It uses computer technology to assist language instruction by increasing PowerPoint, video and other visual elements on the basis of traditional classroom teaching of English listening. It provides a vivid threedimensional context with images and sounds, and integrates several modalities of viewing, listening and speaking into a whole, which contains much information than uni-modal listening classroom and attracts more attention from students.

Modality refers to the way that humans interact with external environment, such as people, machines, objects, animals, etc. through sense of sight and hearing, etc., and the way to interact in three or more senses is called multimodality $(\mathrm{Gu}, 2007)$. Van Leeuwen (2005, p: 281) argues that "multimodality means the combination of different semiotic modes - for example, language and music - in a communicative artifact or event". Baldry and Thibault (2006, p: 21) holds that it "refers to the diverse ways in which a number of distinct semiotic resource systems are both co-deployed and cocontextualized in the making of a text-specific meaning".

Some researchers conducted multimodal study of English audiovisual education from different perspectives (Xie \& Dong, 2010; Liu \& Hu, 2011; Zeng, 2011; Wang \& Yang, 2014; Dang, 2017). Their researches were mainly concerned with theoretical explanation and design concept but lacked practical test. The author makes a case study on multimodality teaching in a college English course of viewing, listening and speaking for undergraduates, which fully shows its advantages. It is a useful exploration for teaching reform of college English listening and speaking lesson.

\section{RESEARCH CONTENT}

The study was carried out among the undergraduates of Grade 2014 majored in accounting in School of Economics and Management in Dezhou University. There were 86 students in the class, including 66 girls and 20 boys. They had college English course of viewing, listening and speaking in a multimedia classroom, which contained two class periods in a week. The content of research was the part of outside view in the third unit of the first volume in the textbook of New Standard College English Real Communication: Listening and Speaking. Teaching procedures were as follows. First, review learning content last week. Then, lead in the topic of new lesson with PowerPoint slides. Next, watch the video of mind mapping and do exercises in the textbook. After that, present the mind map of environmental protection in paper or PPT made by students. In the end, the teacher should make some comments on their performance. The whole multi-modal teaching process (Zhang, 2009) is following, which lasts a total of 50 minutes long. 


\subsection{Language}

\subsubsection{Pure language}

Traditionally, media forms that realize the communication of meaning include sound symbols transmitted by acoustic wave and writing symbols generated by pens etc. These two kinds are main media that language communicates information. Along with rapid development of modern information technology, other technology begin to be used in the communication of language information, such as text entry of the computer, automatic speech recognition etc., but the ultimate communication medium is still voice or character.

Table2.1. Language medium: pure language

\begin{tabular}{|c|c|c|}
\hline Name & & Content \\
\hline \multirow{4}{*}{ Voice } & \multicolumn{2}{|c|}{ Text video lasts for 6 minutes 31 seconds. } \\
\hline & \multicolumn{2}{|l|}{ The teacher gives a lesson. } \\
\hline & \multicolumn{2}{|l|}{ Students answer questions. } \\
\hline & \multicolumn{2}{|c|}{ Students present their works. } \\
\hline \multirow{5}{*}{ Character } & \multirow{3}{*}{ Textbook on p.30 \& p.31 } & 6 exercises \\
\hline & & 1 vocabulary list \\
\hline & & Words on 1 mind map \\
\hline & PowerPoint slide & 13 PPTs \\
\hline & Students' works & 11 mind maps on environmental protection \\
\hline
\end{tabular}

\subsubsection{Paralanguage}

Paralanguage, including sound, tone, volume, audio, accent, mood, font size, font shape and font layout, etc., has the effect of auxiliary, complement and reinforcement on the transmission of language meaning. It plays a very important role in the expression of whole meaning, and sometimes even causes a change in the whole meaning.

Table2.2.1 Language medium: paralanguage

\begin{tabular}{|c|c|c|}
\hline Name & & Content \\
\hline \multirow{4}{*}{$\begin{array}{l}\text { Sound } \\
\text { and } \\
\text { tone }\end{array}$} & Text video & $\begin{array}{l}\text { The teacher in the video gives a clear and bright voice in American English with } \\
\text { rising intonation. Her voice frequency is a little fast in standard pronunciation } \\
\text { with the mood of encouragement and inducement. Students in the video have } \\
\text { clear voices in a few words. }\end{array}$ \\
\hline & $\begin{array}{l}\text { The teacher } \\
\text { gives a lesson }\end{array}$ & $\begin{array}{l}\text { The teacher in the classroom gives a loud voice in British English with the } \\
\text { combination of rising and falling intonation. His voice frequency is moderate in } \\
\text { standard pronunciation with the mood of encouragement. }\end{array}$ \\
\hline & $\begin{array}{l}\text { Students } \\
\text { answer } \\
\text { questions }\end{array}$ & $\begin{array}{l}\text { Students in the classroom answer questions collectively in low voice with falling } \\
\text { intonation. Their voice frequency is a little slowly in nonstandard pronunciation } \\
\text { with the mood of sluggishness. }\end{array}$ \\
\hline & $\begin{array}{l}\text { Students } \\
\text { present their } \\
\text { works }\end{array}$ & $\begin{array}{l}\text { Students give clear voices in British English with mostly correct intonation. Their } \\
\text { voice frequency is a little fast in relatively standard pronunciation with rapid } \\
\text { mood. }\end{array}$ \\
\hline \multirow{3}{*}{$\begin{array}{l}\text { Font } \\
\text { layout }\end{array}$} & Textbook & $\begin{array}{l}\text { It is Times New Roman in English and Song typeface in Chinese. The type size is } \\
\text { moderate. The line spacing is a little narrow. The title and introduction are bold } \\
\text { type with the title of colorful words. The layout is simple, elegant and salient. } \\
\text { The vocabulary list, mind map and questions have a vivid three-dimensional } \\
\text { design. }\end{array}$ \\
\hline & $\begin{array}{l}\text { PowerPoint } \\
\text { slide }\end{array}$ & $\begin{array}{l}\text { It is Century Gothic in English. The type size is a little small. The line spacing is } \\
\text { moderate. The main content is bold type with the title of colorful words. The } \\
\text { layout is salient, vivid, and simpler with pictures. }\end{array}$ \\
\hline & $\begin{array}{l}\text { Students' } \\
\text { works }\end{array}$ & $\begin{array}{l}\text { They are different type sizes with colorful words and proper bold type. The } \\
\text { layout is salient, vivid, and lovely with many cartoon-like figures. }\end{array}$ \\
\hline
\end{tabular}

\subsection{Non-language}

Non-language media that realize the communication of meaning include the communicator's physical movements and one's nonverbal means, such as tools, environment, etc., in the expression of meaning. The physical movements cover motion and analogy; facial features, for example the expressions of face, eyes and other sense organs; body, including gesture, posture, shaking, etc. 
Table2.3 Non-language medium: physical movements

\begin{tabular}{|c|c|c|}
\hline Name & & Content \\
\hline \multirow{3}{*}{$\begin{array}{l}\text { Motion } \\
\text { and } \\
\text { analogy }\end{array}$} & $\begin{array}{l}\text { The teacher in } \\
\text { the video }\end{array}$ & $\begin{array}{l}\text { She walks around in front of the whiteboard occasionally and is close to } \\
\text { students. }\end{array}$ \\
\hline & $\begin{array}{l}\text { The teacher in } \\
\text { the classroom }\end{array}$ & $\begin{array}{l}\text { He steps down from the platform to walk around properly in front of the } \\
\text { students in the first line and at times stands in front of the students in the back } \\
\text { row. }\end{array}$ \\
\hline & esent & They stand on the platform and hold their mind maps with stiff movements. \\
\hline \multirow{3}{*}{$\begin{array}{l}\text { Facial } \\
\text { features }\end{array}$} & $\begin{array}{l}\text { The teacher in } \\
\text { the video }\end{array}$ & $\begin{array}{l}\text { She is smiling with natural expression and soft } \\
\text { attention to reactions from students. }\end{array}$ \\
\hline & $\begin{array}{l}\text { The teacher in } \\
\text { the classroom }\end{array}$ & $\begin{array}{l}\text { He is smiling occasionally with natural expression and kind eyes and } \\
\text { constantly keeps his eyes on reactions from students in the front row, and also } \\
\text { notices the students in the back row. }\end{array}$ \\
\hline & ent & $\begin{array}{l}\text { Probably nervous, they stare at a corner and can not look straight at students } \\
\text { in the classroom. }\end{array}$ \\
\hline \multirow{3}{*}{ Body } & $\begin{array}{l}\text { The teacher in } \\
\text { the video }\end{array}$ & $\begin{array}{l}\text { She is accustomed to palming out in natural and elegant posture with flexible } \\
\text { and frequent gesture. Then she turns her head appropriately and notices } \\
\text { students' expressions. }\end{array}$ \\
\hline & $\begin{array}{l}\text { The teacher in } \\
\text { the classroom }\end{array}$ & $\begin{array}{l}\text { He is accustomed to palming out in natural posture with the gesture of } \\
\text { moderate frequency. Then he sometimes bends his legs with positive regard } \\
\text { for students' expressions. }\end{array}$ \\
\hline & $\begin{array}{l}\text { Students present } \\
\text { their works }\end{array}$ & They have upright posture and appear to be some stiffness with less gesture. \\
\hline
\end{tabular}

Non-physical movements include tools and environment and the communicator can use any existing relevant factors in the environment, including on-site people and objects and symbolic signs, etc., to communicate with each other.

Table2.4 Non-language medium: non-physical movements

\begin{tabular}{|c|c|c|}
\hline Name & & Content \\
\hline \multirow[b]{3}{*}{ Tools } & $\begin{array}{l}\text { Audio } \\
\text { amplifier }\end{array}$ & $\begin{array}{l}\text { There are } 2 \text { cassette players in front of the platform for receiving listening } \\
\text { materials by earphones. On the two sides of it there is } 1 \text { speaker each, and on } \\
\text { the two sides of the middle of the classroom there is also } 1 \text { speaker each. They } \\
\text { can always play audio material in better quality. }\end{array}$ \\
\hline & PPT & $\begin{array}{l}\text { 1. In used modes, there are } 8 \text { verbal modes, } 1 \text { language and image mode, and } 4 \\
\text { image modes. } \\
\text { 2. In discourse genre, there are } 4 \text { visualizing genre to make real impressions } \\
\text { by means of pictures, and } 9 \text { persuading genre to make audience understand } \\
\text { the meaning of materials and realize the purpose of persuading by color, } \\
\text { cartoon and music, etc. }\end{array}$ \\
\hline & Text video & $\begin{array}{l}\text { 1. In information value, the teacher is always in the middle of the video on a } \\
\text { prominent position and students are only in the corner of two sides on } \\
\text { weakened positions. The whiteboard behind the teacher is the object to be } \\
\text { handled with by her and focused on by students and audience. The teacher } \\
\text { is sometimes on the left side in given information. } \\
\text { 2. In salience, the foreground is the teacher close to audience in black suits } \\
\text { which make her stand out; the background is the tawny door in the room } \\
\text { with soft light which makes people feel tedious and does not fit for study. } \\
\text { Moreover, with the added whiteboard, the space is very narrow. } \\
\text { 3. In framing, there is not evident type of framing segregation, which closes } \\
\text { the gap between audience and participants in the video and develops the } \\
\text { intimacy of audience. }\end{array}$ \\
\hline Environment & Classroom & $\begin{array}{l}\text { A multimedia classroom with } 260 \text { seats includes } 1 \text { computer, } 1 \text { master control } \\
\text { device for DVD player and speaker, } 1 \text { projector, and } 1 \text { projection screen. }\end{array}$ \\
\hline
\end{tabular}

\section{CONClusion}

In college English listening and speaking instruction, the application of multimodality should be appropriate, and thus teachers cannot indiscriminately throw a lot of multimodal medium at students, which is easy to distract their attentions so that they struggle to cope with and are unable to assimilate 
new information. Only by serving teaching contents does the application of multimodality have practical significance.

Then, teachers should reasonably use media system of multimodal discourse but not overly be dependent on the means, such as PowerPoint slides, video, etc. It is advisable to give free rein to the function of the media, for example language, motion, face, body, etc., to close the gap with students' mind and raise their awareness of good feelings to enhance the comprehensive quality.

Finally, teachers are supposed to make plans to give students multimodal knowledge and cultivate their ability to learn and master the subject knowledge in the style of modal cognition they are good at and increase their ability of autonomous learning.

\section{REFERENCES}

[1] Baldry, A. \& Thibault, P. J. (2006). Multimodal Transcription and Text Analysis. London: Equinox.

[2] Dang, J. (2017). An Action Research on Multimodal College English Audio-visual Teaching. Journal of Anhui Vocational College of Electronics \& Information Technology, 16(4), 68-71.

[3] Gu, Y. G. (2007). On Multimedia Learning and Multimodal Learning. Computer-Assisted Foreign Language Education, 114 (2), 3-5.

[4] Liu, M. \& Hu, J. S. (2011). Designing of Audio-visual Listening Coursebooks for College English on the Basis of Multimodality. Computer-Assisted Foreign Language Education, 138(2), 3-8.

[5] Van Leeuwen, T. (2005). Introducing Social Semiotics. London: Routledge.

[6] Wang, J. \& Yang, Y. (2014). The Positive Impact of Multimodal Intervention Strategies on Chunk Learning and Listening Skills. Foreign Languages in China, 11(6), 43-52.

[7] Xie, J. X. \& Dong, J. Q. (2010). On Teaching College English Listening_Based on Multimedia and Multimodal Teaching and Learning. Computer-Assisted Foreign Language Education, 136(6), 9-13.

[8] Zeng, Q. M. (2011). The Efficacy of Multimodal Teaching on the Development of L2 Listening and Speaking Abilities. Journal of PLA University of Foreign Languages, 34(6), 72-76.

[9] Zhang, D. L. (2009). On a Synthetic Theoretical Framework for Multimodal Discourse Analysis. Foreign Languages in China, 6(1), 24-30.

\section{AUTHOR'S BIOGRAPHY}

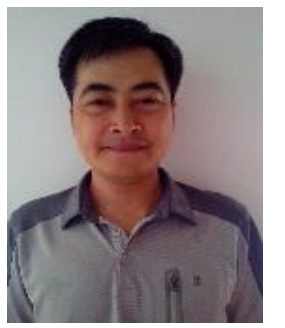

Ji Song earned a master degree in English Language and Literature from China University of Petroleum in china in 2006. He is an associate professor at College English Teaching Department, Dezhou University. And he is also an author of papers published in local and international journals. His areas of interest include, but are not limited to, Computer Assisted Language Learning and Foreign Language Teacher Professional Development.

Citation: Ji Song. "A Case Study on Multimodality Teaching in a College English Listening and Speaking Course" International Journal on Studies in English Language and Literature (IJSELL), vol 6, no. 1, 2018, pp. 1-4. doi:http://dx.doi.org/10.20431/2347-3134.0601001.

Copyright: (C) 2018 Authors. This is an open-access article distributed under the terms of the Creative Commons Attribution License, which permits unrestricted use, distribution, and reproduction in any medium, provided the original author and source are credited. 